\title{
Sobre cerámicas Helenísticas en Iberia / Hispania. Significado y funcionalidad ${ }^{1}$ \\ Iconography on Hellenistic wares in Iberia / Hispania. Meaning and functionality
}

\author{
José Pérez Ballester \\ Universitat de València. Departamento de Prehistoria y Arqueología
}

A Ricardo Olmos, maestro, colega y amigo

\begin{abstract}
RESUMEN
En este trabajo haremos un recorrido cronológico y tipológico estudiando la iconografía que aparece en las cerámicas helenísticas importadas del Mediterráneo Central y Oriental entre los siglos III y II a.C. en la Hispania Citerior, en especial de Cartagena. Analizaremos su funcionalidad en los lugares de origen, y con ayuda de los contextos hispanos concluiremos si su presencia aquí es consecuencia de una dinámica comercial determinada, o responde a una preferencia decorativa, de gusto o moda; o bien si las imágenes son significantes ligados a usos rituales o conviviales concretos, públicos o privados, por parte del habitante local que los adquiere y utiliza.
\end{abstract}

\section{SUMMARY}

In this work we are going to take a chronological and typological tour by studying the iconography that appears in the Hellenistic wares imported from the Central and Oriental Mediterranean between $3^{\text {rd }}$ and $2^{\text {nd }}$ centuries BC in Hispania Citerior, in particular from Cartagena. We are going to analyze its functionality in the places of origin, and with the help of the Hispanic contexts we will conclude whether its presence here is a consequence of a certain commercial dynamic, or if it answers to a decorative preference, of taste or trend; even if the images are significant related to ritual or convivial uses, public or private, by the local inhabitant who acquires and uses them.

PALABRAS CLAVE: Iconografía, cerámicas helenísticas, Gnathia, cuencos de relieves, fíalas, laginos, Klíbanos.

KEY WORDS: Iconography, Hellenistic wares, Gnathia, bowls of reliefs, phiales, lagynos, klibanos.

${ }^{1}$ Este trabajo se ha realizado en el marco del Proyecto HAR2009-11116 del Ministerio de Ciencia e Innovación.

\section{ICONOGRAFÍA VASCULAR ITÁLICA AL INICIO DE LA $2^{\text {a }}$ GUERRA PÚNICA}

\subsection{Las copas "De Gnathia"}

\subsubsection{Talleres e iconografía}

Las encontramos en la costa mediterránea peninsular, especialmente al sur del Ebro y sobretodo en Cartagena y su área de influencia, durante la segunda mitad del s. III en niveles arqueológicos de época bárquida. Se trata de cerámicas sobrepintadas apulas 'De Gnathia' del denominado 'Alexandria Group' (Green 1982: 256-257; 2001; Pérez Ballester 2002: 33-40; Ruiz Valderas 2008), junto a otras minoritarias campanas (Teano y similares) o sicilianas ${ }^{2}$ (Fig. 1).

Las cerámicas 'De Gnathia' presentan en un primer momento (primera mitad a tercer cuarto del siglo Iv) motivos figurados explícitos de iconografía dionisíaca: ménades, erotes, máscaras; pero pronto (fines del siglo iv e inicios del III) sus vasos aparecerán decorados solo con motivos mucho más simples pertenecientes siempre al ámbito de lo dionisíaco en su triple vertiente: simposion-consumo de vino, teatro y mundo funerario. A las máscaras ahora se suman antorchas, cintas, instrumentos musicales, crateras y palomas o cabecitas femeninas de perfil

2 Sobre el uso del término 'De Gnathia': Pérez Ballester 2002: 26-28. Un completo estado de la cuestión sobre el 'Alexandria Group' en el mismo libro, 33-43; y más recientemente en Ruiz Valderas 2008. 


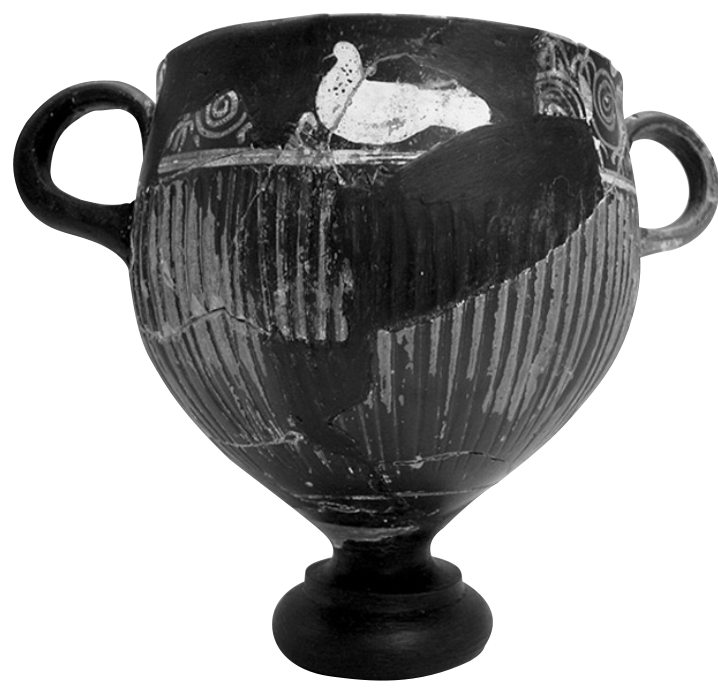

Figura 1. Copa de Gnathia, "Alexandria Group". Alhama de Murcia. (Foto Museo de Alhama).

como máximo alarde figurativo. Estos elementos aparecen pintados en vivos colores sobre el barniz negro del fondo, aislados en el campo del vaso, a menudo enmarcados con guirnaldas formadas por la rama de vid con sus racimos de uva, pámpanos, hojas y zarcillos o por ramas de hiedra, quizás alusiones a lo que se ha llamado 'el eterno y felicísimo jardín de Dionisos’ (Cabrera 1998).

Cabecitas femeninas y palomas entre roleos vegetales, guirnaldas de hiedra, así como otras más esquemáticas tipo mirto 'a ramo secco', pintadas en blanco y amarillo, son los motivos más frecuentes que encontramos en crateriscos y sobre todo copas hemiesféricas con el cuerpo agallonado, asas verticales y pie realzado del 'Alessandria Group'. Tras la revisión de las necrópolis tarentinas (De Juliis 1985; Lippolis 1996) pueden fecharse en pleno siglo III, pudiendo llegar incluso a inicios del II a.C. En Cartagena aparecen en contextos bárquidas y prebárquidas, siempre dentro de la segunda mitad del siglo III (Ruiz Valderas 2004: 90-92).

\subsubsection{Llegada y distribución en Hispania}

Son varios los problemas que se nos plantean. El primero de ellos, el derivado de la llegada a nuestras costas de estas cerámicas. Un repaso sobre la distribución de las mismas en la Península Ibérica (Pérez Ballester 2002: 33-40; Ruiz Valderas 2008; Jaeggi 1999: Karte 10) nos informa que más del $75 \%$ de las piezas aparecieron en la ciudad de Cartagena (una cincuentena) y en su área de influencia inmediata, desde Almería hasta Alicante (5 ejs.) (Fig. 2). El resto, 6 piezas de Sagunto y su área de influencia (Betxí, Vinarragell) una en Ibiza, dos en Menorca y 5 en Cataluña, concentradas allí en los oppida de Burriac (Cabrera de Mar) y de Molí d'Espigol (Tornabous), mientras que algunos enócoes, escifos y crateriscos sobrepintados en blanco de Ampurias y Ullastret (6 ejs. en total) podrían ser de origen apulo, aunque no del "Alessandria Group" (Pérez Ballester, 2002: 40). Otros objetos de comercio que podrían ser de la misma época y que encontramos en el área de Cartagena son las ánforas vinarias grecoitálicas MGS V y sobre todo las MGS VI, de procedencia siciliana o magnogreca que también han aparecido asociadas a cerámicas 'De Gnathia' en algún pecio, precisamente cerca de Tarento (La Madonnina: McCann 1972). Unas y otras podrían llegar juntas a Cartagena (Fig. 3) y pensamos que a través de un intermediario púnico (Martín Camino 1996; Pérez Ballester 2004).

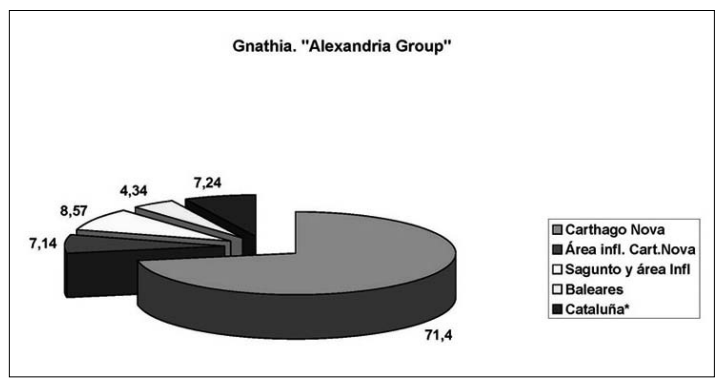

Figura 2. Distribución de las cerámicas sobrepintadas del "Alexandria Group" en la Península Ibérica (elaboración propia).

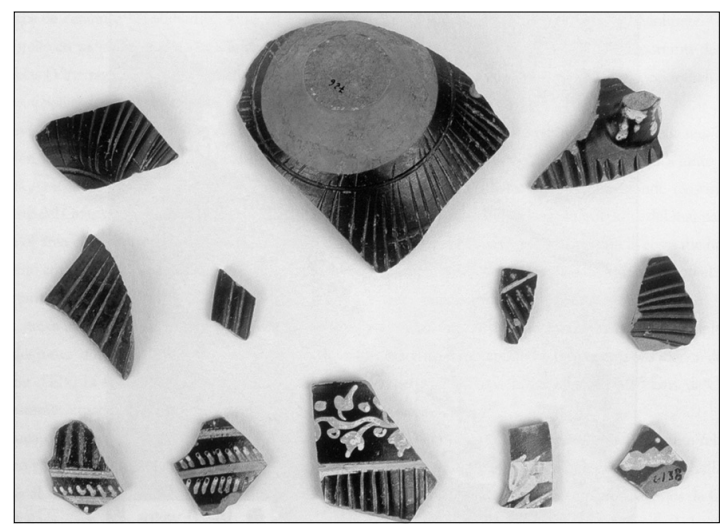

Figura 3. Cerámicas del "Alexandria Group" procedentes de Cartagena (Pérez Ballester 2002). 


\subsubsection{Aquí y allí. Cuestiones de contextos y funcionalidad}

Estos vasos aparecen en Tarento y en la Messapia en contextos funerarios y excepcionalmente en contextos sacros, ${ }^{3}$ mientras que no se conocen en ajuares domésticos. La iconografía de los mismos encaja bien allí con esa funcionalidad de libación u ofrenda de vino al difunto o a la divinidad: las plantas favoritas del dios que volvió del Hades (guirnaldas de vid, hiedra y mirto); la cabeza femenina o ánodos renaciendo de entre la vegetación, o la paloma, símbolo de Afrodita pero también del amor que perdura tras la muerte, que encontramos en las grandes crateras funerarias de figuras rojas apulas; o las alusiones a ritos nocturnos con antorchas y música, identificaban claramente al devoto italiota con el objeto ofrecido.

Pero en la Península Ibérica sólo encontramos dos de estos vasos en contexto de necrópolis: uno en el Puig des Molins (Ibiza), vasito miniaturístico que no es del 'Alessandria Group' (Pérez Ballester 1994b), con decoración de guirnalda de vid; el otro es un fragmento de pie de copa o crateriscos, en la necrópolis ibero-púnica de La Albufereta de Alicante, este sí del 'Alessandria Group'. Los hallazgos son urbanos, ya sean en la ciudad de Cartagena, con materiales mayoritariamente de importación púnicos e itálicos en oppida indígenas sin contexto o en niveles arqueológicos, siempre de finales del siglo III e inicios del II (Pérez Ballester 2002: 33-43). Creemos que el indígena adopta estas copas como recipientes para beber, quizás para consumir un vino exótico y preciado (aunque esto no excluye la existencia de producción de vino en ámbitos locales, como se ha demostrado en diferentes lugares del actual País Valenciano). Al aceptar el vaso acepta también su iconogafía, que no le era extraña, pues tanto los motivos figurados de las palomas como las guirnaldas de hiedra las conocemos en falcatas y otros objetos de metal ibéricos, o en cerámicas y vasos plásticos de los siglos IV y III (Pérez Ballester 1997; Pérez Ballester y Gómez Bellard 2004); y es posible que de este modo vinculase estos motivos iconográficos a sus referentes simbólicos

\footnotetext{
${ }^{3}$ En una visita a Lecce y Tarento hemos podido tener en nuestras manos las cerámicas sobrepintadas 'De Gnathia' y en especial las del 'Alessandria Group', procedentes de la Messapia, de las necrópolis de Vaste, Rudiae, Oria, Rocavecchia, o del santuario de Monte Papalucio en Oria; así como de las necrópolis de Taranto. Mi agradecimiento a los profesores F. D'Andria, G. Semeraro y el doctor G. Mastronuzzi, de la Università di Lecce; a la directora del Museo Naciona Arqueológico de Tarento, A. dell' Aglio, y a la conservadora A. D'Amicis, por su inestimable ayuda y atención.
}

sacros, como creemos que se ha demostrado al estudiar el motivo de la paloma (Pérez Ballester y Gómez Bellard 2004: 37-44). El uso de estos vasos en ritos domésticos o públicos queda de momento como mera hipótesis, al no haberse documentado asociaciones claras en estos contextos.

\subsection{VASOS BARNIZADOS CON DECORACIÓN EN RELIEVE}

Nos referimos a los vasos itálicos que sustituyeron en su inicio a prototipos metálicos helenísticos cuya decoración reproducen, como ocurre con las fíales mesónfalas en su mayoría de origen caleno; ${ }^{4}$ o que, siguiendo una moda o gusto helenístico llevó a los ceramistas a partir del siglo III a decorar a molde o mediante relieves aplicados copitas de pie alto y páteras o cuencos profundos de paredes abiertas, herederas de los mastoi griegos. Son vasos de barniz negro, ocasionalmente rojo, de producción no masiva, decorados con motivos muy variados (Pedroni 2001: 149-153) y que en algún caso derivaron en alguno de los modelos de la Campaniense A (p.e. la forma L33a, Morel F-2154, con pseudopie y decoración pintada, incisa y en relieve, o la F-2820, con pie anular y a menudo una cabeza femenina en relieve en el fondo interno). Contemporáneamente pero en Oriente, talleres áticos y jónicos producen a molde boles o cuencos hemiesféricos con decoración en relieve por el exterior, barnizados en negro. Su producción más tardía, con engobes de color no uniforme que va del negro al rojo, de superficie iridiscente o mate, llega también a nuestras costas pero ya hacia el último cuarto del siglo II a.C. como veremos.

Los más antiguos, ahora agrupados en la cerámica de barniz negro de la Calena Arcaica (Pedroni 2001: 147-161) llegan a la Península Ibérica en la segunda mitad del siglo III. Los hallamos en contextos del último cuarto de ese siglo y de inicios del II, concentrados en los primeros puertos romanos republicanos de Carthago Nova y Tarraco, en otros más antiguos como Emporiae o Saguntum y en sus entornos litorales. Por último, unos pocos en el área pre-litoral como en el oppidum ibérico de La Serreta o en zonas mineras muy concretas, como las de Carthago Nova o de Jaén. Se trata de fialas mesónfalas (Morel F-2170), cuencos profundos ápodos de paredes abiertas (Morel, F-2157) o con pie anular (Morel F-

\footnotetext{
${ }^{4}$ Un exhaustivo estado de la cuestión, con toda la bibliografía sobre el tema, puede verse en Pedroni 2001: 62-95 y 109-163.
} 
2820). Algo más reciente, dentro de la Calena Antigua (200-130/120 a.C.), encontramos también en Hispania la paterita Morel F-1153 (Pedroni 2001: $163)$, igualmente decorada con motivos en relieve.

\subsubsection{Las fíalas mesónfalas}

\subsubsection{Iconografía y distribución}

Fueron identificadas desde un primer momento como calenas por el hallazgo de matrices en esa ciudad. De los 22 motivos decorativos presentados en el gran trabajo de Pagenstecher ${ }^{5}$ al menos 16 son calenos (Pedroni 2001: 148-153). Los temas son muy variados, destacando los denominados ornamentschale o de cáliz (Blütenkelchphialen) (Fig. 4), fíalas cubiertas por una decoración vegetal de hojas lanceoladas imbricadas $(36,3 \%)$, seguidos de los relacionados claramente con el mundo dionisíaco (erotes o putti en diversas actitudes y escenas, thiasos báquico, 21,2\% del total), otros mitológicos (Helios y Heracles, $18,1 \%$ ) o específicamente del ciclo homérico (Odyssenschale, 12,1\%). Naves o proas de naves, filas de animales o guinaldas florales apenas tienen un ejemplar cada uno.

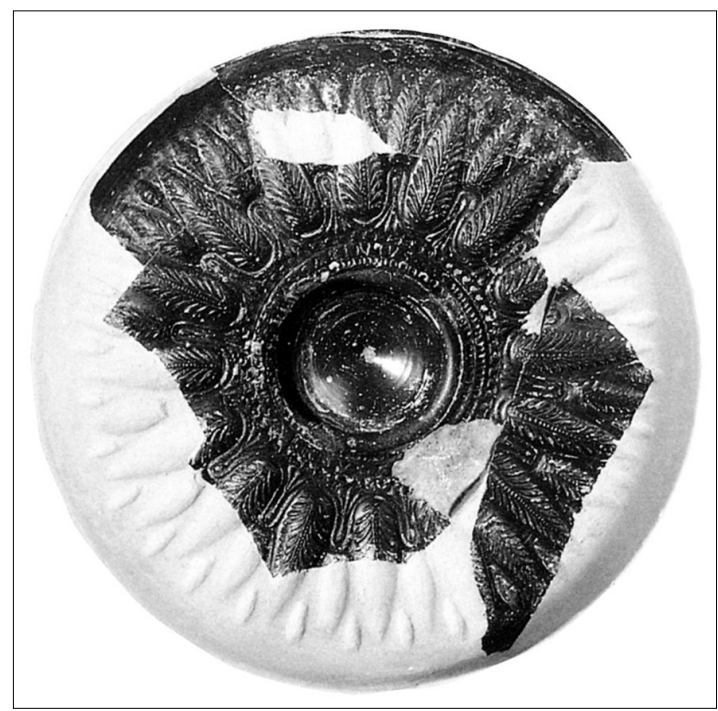

Figura 4. Fiala mesónfala de barniz negro con decoración de hojas imbricadas (ornamentschale). Necrópolis de Castiglioncello (Gambogi y Paladino, 1999).

${ }^{5}$ Pagenstecher 1909. Un tratamiento general del tema, en Rocco 1959 y el estado de la cuestión hasta los años 80, en Morel, 1981. La discusión más documentada, en Pedroni 2001.
En Hispania estas piezas son una veintena, en su mayoría fragmentos, ${ }^{6}$ de los que ocho se han encontrado en Carthago Nova, cuatro en tierras valencianas y otras seis en Cataluña, a las que hay que añadir uno de la mina Diógenes (Jaén). Los temas que aparecen en ellas coinciden en parte con los más comunes entre la variada iconografía de estas páteras: los Ornamentschale (5 ejs.), coincidiendo con su abundancia en el área calena y en Etruria como ahora veremos. Igualmente frecuentes son las que representan la Apoteosis de Herakles (5 ejs.) (Fig. 5); otros dionisíacos (Erotes, 3 ejs.) varios fragmentos con motivos vegetales ( 3 ejs.) u otros dos con el carro de Helios. Concretamente en Cartagena, se reparten entre Ornamentschale, Apoteosis, Erotes y motivos vegetales (dos ejemplares cada uno).

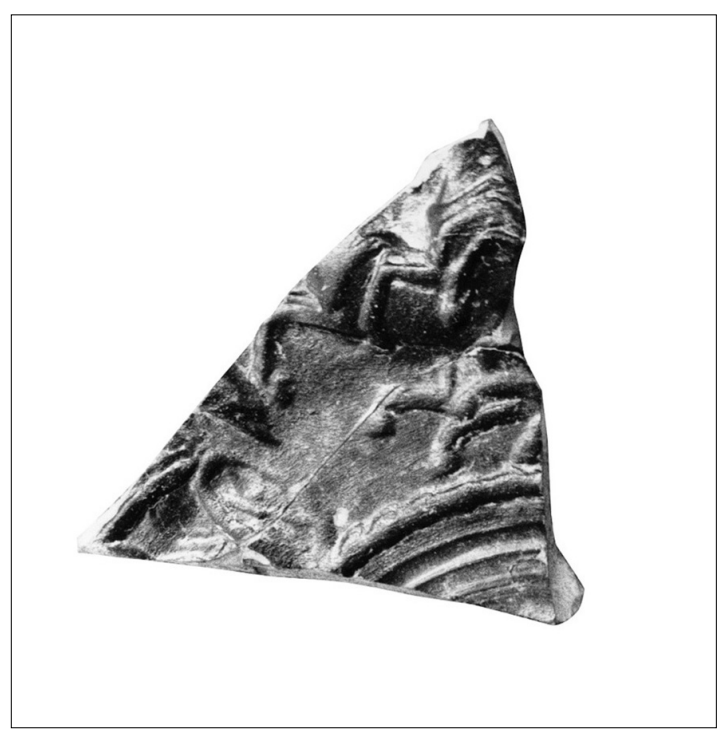

Figura 5. Fragmentos de fíala mesónfala de barniz negro con el motivo de la Apoteosis de Heracles. Molinete, Cartagena. Foto Museo Arqueológico Municipal de Cartagena.

Los dos primeros temas que hemos mencionado, las Ornamentschale y la Apoteosis de Herakles son los más abundantes en el área etrusca, donde incluso se ha hablado de talleres propios o del establecimiento allí de un ceramista caleno, en la primera mitad del siglo III (Sanesi 1986; Pedroni 2001: 138-139). La publicación de fialas faliscas no solo de barniz negro, sino también en cerámica 'argentata' con estos temas, fechadas a finales del siglo IV o inicios del III, imitando claramente a otras de oro y plata más antiguas (De

6 Ver algunas recopilaciones en Puche 1998, Principal 1998; Ruiz Valderas 1999 y Jaeggï 1999; Cabrera 2004. 
Lucia Brolli y Michetti 2005), abogan por una producción paralela. Su éxito en Etruria se observa también en la presencia de fíalas con motivo de Ornamentscha$l e$ en las manos de los difuntos representados en numerosas tapaderas de sarcófagos etruscos de la segunda mitad del siglo IV y del III.

\subsubsection{Aquí y allí. Cuestiones de contextos y funcionalidad}

En cuanto a su funcionalidad, la misma forma de la pátera nos dice que nos encontramos ante un vaso ritual, que aparece desde época arcaica en el mundo griego fabricada en metal y también en la Magna Grecia ya en cerámica en la misma época. ${ }^{7} \mathrm{La}$ encontramos en numerosas representaciones plásticas o vasculares griegas en manos de divinidades, sacerdotes, escanciadores y devotos, formando servicio con el enócoe para libar o servir vino. Como objeto real, en depósitos votivos y también en tumbas. En todos estos casos suelen estar decorados con hojas imbricadas, que es al parecer el motivo más antiguo (Lippolis 1994: 246). En Etruria su funcionalidad es claramente funeraria, y en este sentido el tema del ascenso de Herakles al Olimpo es pertinente con su deposición en la tumba; mientras que para Massa-Peirault (2005:14) las halladas en la necrópolis de Spina (costa nordadriática) y otros lugares, tanto de metal como cerámicas, por la temática de cuádrigas podrían aludir al triunfo y a los ludi, dentro de un contexto funerario ya plenamente romano. Creemos que esto es difícil de aplicar a las fíalas metálicas, más antiguas.

Volviendo a las de la Península Ibérica, estas páteras en ningún caso se asocian a contextos funerarios, para los que su iconografía dionisíaca o hercúlea podría encajar perfectamente, como hemos visto más arriba. Las encontramos en ciudades y oppida como Emporiae, ${ }^{8}$ Tarraco, La Serreta (Alcoi) (Fig. 6), Tossal de Manises (Alicante), L'Alcúdia (Elx) o en Carthago Nova; aunque cuando conocemos su contexto, están relacionadas con áreas sacras públicas o privadas, como vemos en Tarraco (Puche 1998, 110) y La Serreta (Abad 1983: 178-185). En Carthago

\footnotetext{
${ }^{7}$ Véanse los distintos trabajos de G. Richter sobre el particular, y su relación con las producciones cerámicas calenas, en especial 1950 y 1959. Sobre las fíalas en cerámica imitando a las metálicas, desde el siglo viI y con funcionaldad votiva (depósitos en santuarios griegos y suditálicos), ver Lippolis 1994.

${ }^{8}$ Un fragmento publicado; otros dos, sin contexto claro (carro de Helios y Apoteosis), se encuentran en los almacenes, información que debemos a nuestra colega y amiga Marta Santos, directora del Museu d'Empúries.
}

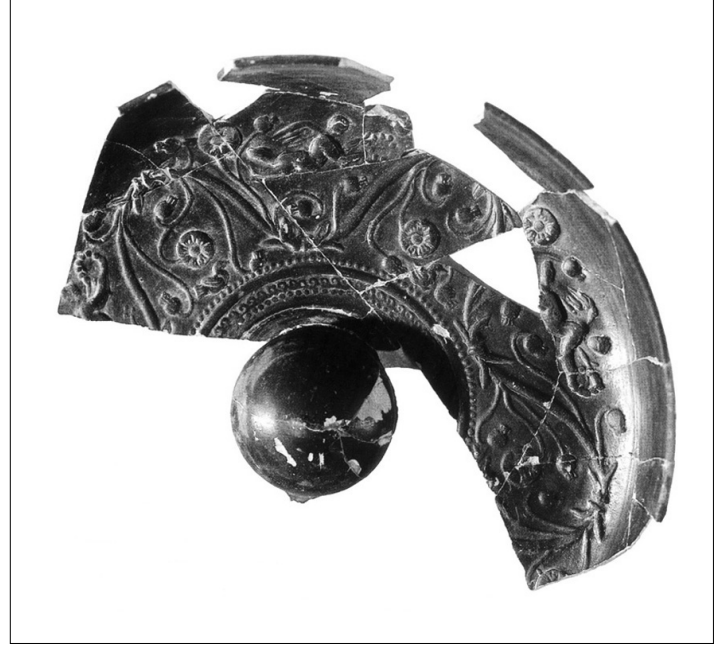

Figura 6. Fíala mesónfala de barniz negro con motivo de $p u$ $t t i$ entre guirnaldas. Poblado ibérico de La Serreta. (Foto Museu Arqueològic d'Alcoi).

Nova, sin contexto claro, son frecuentes en los sectores más próximos al área sacra del Molinete.

\subsubsection{Los copas con medallón central}

\subsubsection{Iconografía y distribución}

También con origen en otras copas de factura metálica, se trata de vasos casi hemiesféricos, de base plana o con pie apenas indicado, fabricados en la península Itálica pero seguramente también en otros centros orientales. En Italia son especialmente numerosos los de barniz negro en Cales, donde conocemos al menos 32 temas (y moldes) distintos repartidos entre una cincuentena de vasos (Pedroni 2001, 148152). ${ }^{9}$

Pero lo que aquí nos interesa es su presencia en la Península Ibérica. Los motivos en relieve aparecen tanto sobre cuencos Morel F-2187 como sobre otros F-2820 con pie anular. Los encontramos en los mismos lugares en donde se documentan las fíalas de relieves, y en sus cercanías. En el área catalana se documentan varios cuencos con cabezas o bustos femeninos, otros con Helios, Nereida y Tritón, cangrejo y rana, máscaras y ave, escena de lucha, etc (Puche 1998: 109-113) (Figs. 7 A-B). En el País

\footnotetext{
${ }^{9}$ Pagenstecher presenta 90 distintos, de los que Pedroni considera solo 32, más dos matrices como calenos (2001, 149). Otros procederían del área campana, como las representaciones de cabezas y bustos femeninos, tan frecuentes en Hispania.
} 

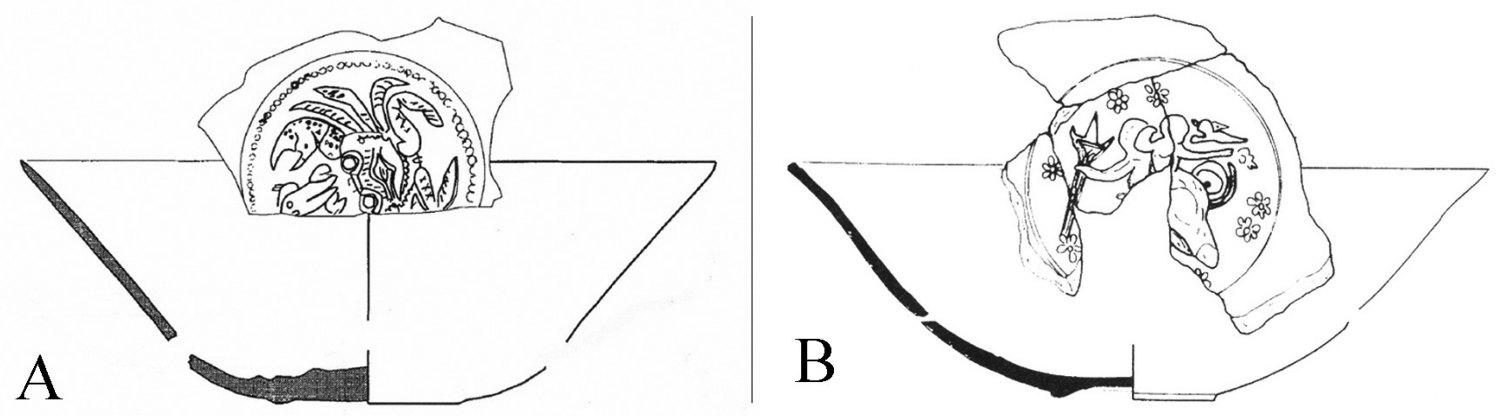

Figura 7. Copas de barniz negro con medallón en relieve en su fondo interno (F- 2157). A): Cangrejo y rana; B): Nereida y Tritón cabalgando un delfín, con pequeño Eros. Tarragona (Puche 1998).

Valenciano, destacamos Saguntum y su territorio, con al menos cuatro cuencos con representaciones de cabezas o bustos femeninos poco claros, posibles Gorgonas, Aretusas o Ménades (Aranegui 1995) (Fig. 8) y un centauro en Valentia; ${ }^{10}$ además, otra copa con cabeza femenina en la necróplis de La Albufereta y varios indeterminados en La Alcúdia (Elx). En Carthago Nova encontramos también una cabeza femenina, un busto de Orfeo con lira, un fragmento con delfines, guirnaldas vegetales (3 ejs.) y una cabeza de Dionisos, este último en el fondo de una copa de barniz rojo de posible origen oriental.

Tampoco en Hispania Citerior son frecuentes sus contextos en necrópolis (sólo un vaso en La Albufe-

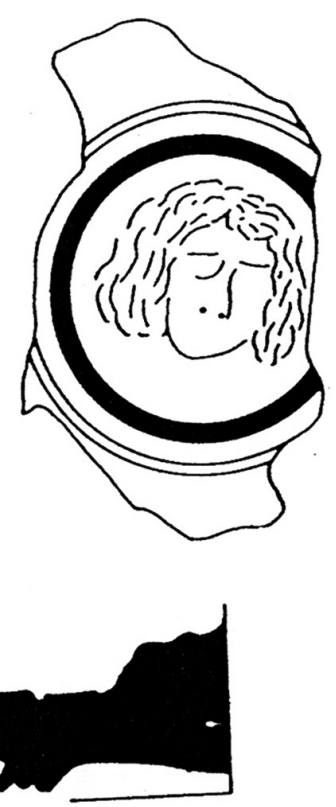

Figura 8. Fondo de copa profunda de barniz negro, con cabeza femenina en relieve. Sagunto (Aranegui 1995).

\footnotetext{
${ }^{10}$ Comunicación de A. Ribera (SIAM).
}

reta), por lo que no podemos pensar que la iconografía de estas copas helenísticas tuviese una funcionalidad ligada a la religiosidad funeraria ibérica (Cabrera 2004: 10-14). Los contextos que conocemos de Tarragona, Sagunto o Cartagena, sitúan estas piezas a finales del siglo III o mejor a inicios del II (Puche 1998: 118; Aranegui 1995: 256; Ruiz Valderas 1999). Tendrían una funcionalidad sacra, pero creemos que de carácter doméstico o privado, como parece indicar el contexto del cuenco con medallón de Tarragona, al que haremos más adelante alusión, representando a una Nereida cabalgando a un delfín con pequeño Eros: se halló en una estancia doméstica, junto a un cernos con cabeza de Core, una antefija con cabeza de Sileno y un animalito de terracota, todos alrededor de una mensa o ara (Puche 1998: 113, fig. 4 y lám. 3,1).

En el área de Cartagena, la copa hallada en la mina de la Balsa a pocos kilómetros de la ciudad con representación de Orfeo con lira, un modelo caleno, (Fig. 9), apareció junto a una fiala con hojas imbricadas u Ornamentschale (Domergue 1969), donde el contacto del minero creyente con el interior de la tierra hace más evidente el uso de la iconografía órfica. Ya en la ciudad, destacamos la base de cuenco del área del Anfiteatro con cabeza de Dionisos, también de inicios del siglo II, y las numerosas pateritas de pie alto Morel F-1153 (una decena), con guirnaldas, ovas en el borde y otros motivos como delfines. Entre ellas destaca un fondo de pátera recortada con medallón en donde se aprecia parte de un personaje con inscripción [C]VPIDO, un pequeño escorpión y un lagarto rodeados de una cenefa de ovas, que merecería un estudio aparte. Procede de La Milagrosa, junto a la Muralla Púnica, de niveles de finales del siglo III - inicios del $\mathrm{II}^{11}$ (Fig. 10). En

${ }^{11}$ Nuestro agradecimiento a Miguel Martín Camino, que nos ha permitido presentar esta pieza. Tanto las piezas del Anfiteatro como las de El Molinete y la Muralla Púnica, pertenecen a niveles de relleno de época republicana (fin siglos III-II a.C.) sin contexto funcional. 
conjunto, vemos una variada representación de motivos figurados relacionados en muchos casos con lo dionisíaco, que salvo contadas excepciones parece que se remite al ámbito de lo privado más que a lo público, en la época republicana a la que nos referimos, coincidiendo con lo que opina Wyler (2004).

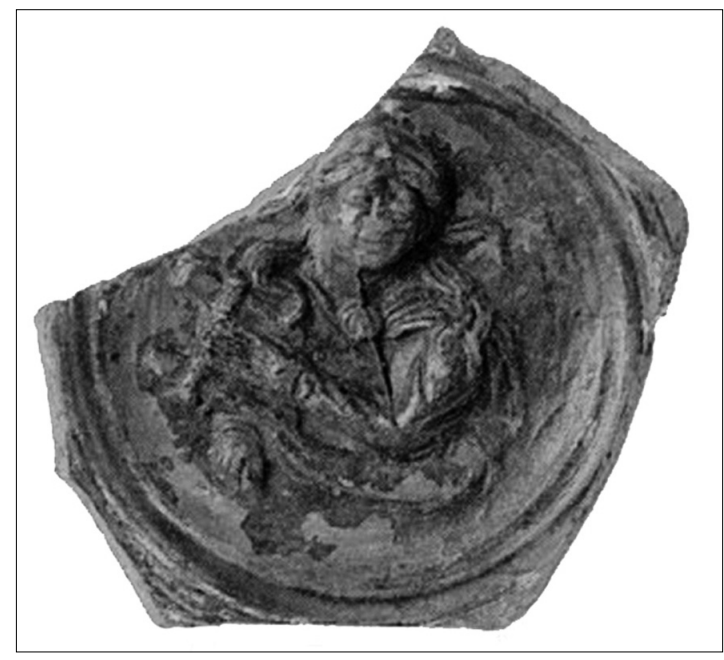

Figura 9. Fondo de copa de barniz negro, con figura de Orfeo u Apolo con lira. Mina de la Balsa, Cartagena. (Domergue 1969).

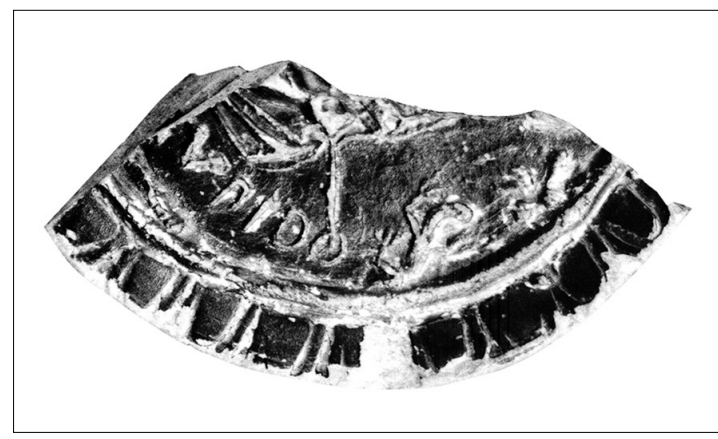

Figura 10. Paterita de barniz negro, posiblemente F-1153. Personaje indeterminado. Debajo: lagartija y escorpión. Leyenda: [C]VPIDO. La Milagrosa, Cartagena. Foto Museo Arqueológico Municipal de Cartagena.

\subsubsection{Aquí: cultos públicos y privados}

Pensamos por tanto que la funcionalidad de fíalas, copas y pateritas decoradas con relieves figurados de origen itálico, que en la Península Ibérica aparecen en los lugares de más temprana romanización como en Cartagena, respondería al seguimiento de unas creencias de tipo helenístico, pasadas por el filtro cultural magnogreco, y que son usadas en ceremonias y rituales de carácter público (fíalas especialmente) o privado (copas especialmente), pero siempre dentro de un ámbito cultural helenístico itálico o tempranamente romanizado, sin que podamos hablar aquí de sincretismo con divinidades o creencias locales, como en su momento sí hemos defendido para otros objetos, en ambientes diferentes y con cronología diversa (Pérez Ballester y Gómez Bellard 2004).

\subsection{Clíbanos con relieves aplicados}

\subsubsection{Funcionalidad, iconografía y distribución}

Se trata de hornillos o braseros cilíndricos o cónicos de cerámica que constan de dos partes: una inferior hueca con apertura para extracción de cenizas y otra superior de base cóncava, con perforaciones y borde abierto provisto de tres apéndices dirigidos hacia el interior, que actúan como soportes para colocar un recipiente (olla o cytra $)^{12}$ (Fig. 11 A- B).

En su mitad superior pueden presentar una decoración en relieve: al exterior rosetas o cabezas de león, mientras que por el interior los apéndices rectangulares pueden ser lisos o llevar una decoración figurada, siendo la representación más frecuente una cabeza masculina tocada con gorro cilíndrico y larga barba, que se extiende por el soporte rectangular. De esta figura se ha dicho que podría representar un Daemon relacionado con el fuego o al mismo Hefaistos (por el gorro cónico de cuero habitual en los que trabajan en las fraguas) (Rotroff 2006: 206) (Fig. 12).

Son frecuentes en todo el Mediterráneo Oriental. Se documentan varios centenares en Atenas y sus alrededores, y casi 3.000 en Delos, quizás allí almacenados para su comercialización (Rotroff 2006: 202). También en un pecio, en las costas de Turquía, interpretado como parte de la dotación culinaria de la nave (Gianfrotta et alii 1997: 107); parece que se utilizó como un instrumento doméstico, útil tanto como hornillo (combustible en la parte superior y recipiente para cocinar alimentos encima) o como calentador o brasero (combustible en el depósito superior). Allí donde se han podido contextualizar arqueológicamente, aparecen desde el primer cuarto del siglo II, siendo los más recientes algunos de Atenas de época silana; aunque los que llevan apén-

12 Véase una introducción con bibliografía, en Siebert 1970; más recientemente, Rotroff 2006, 199 ss.; para la península Ibérica, Dupré 1985, y Pérez Ballester 1998. 


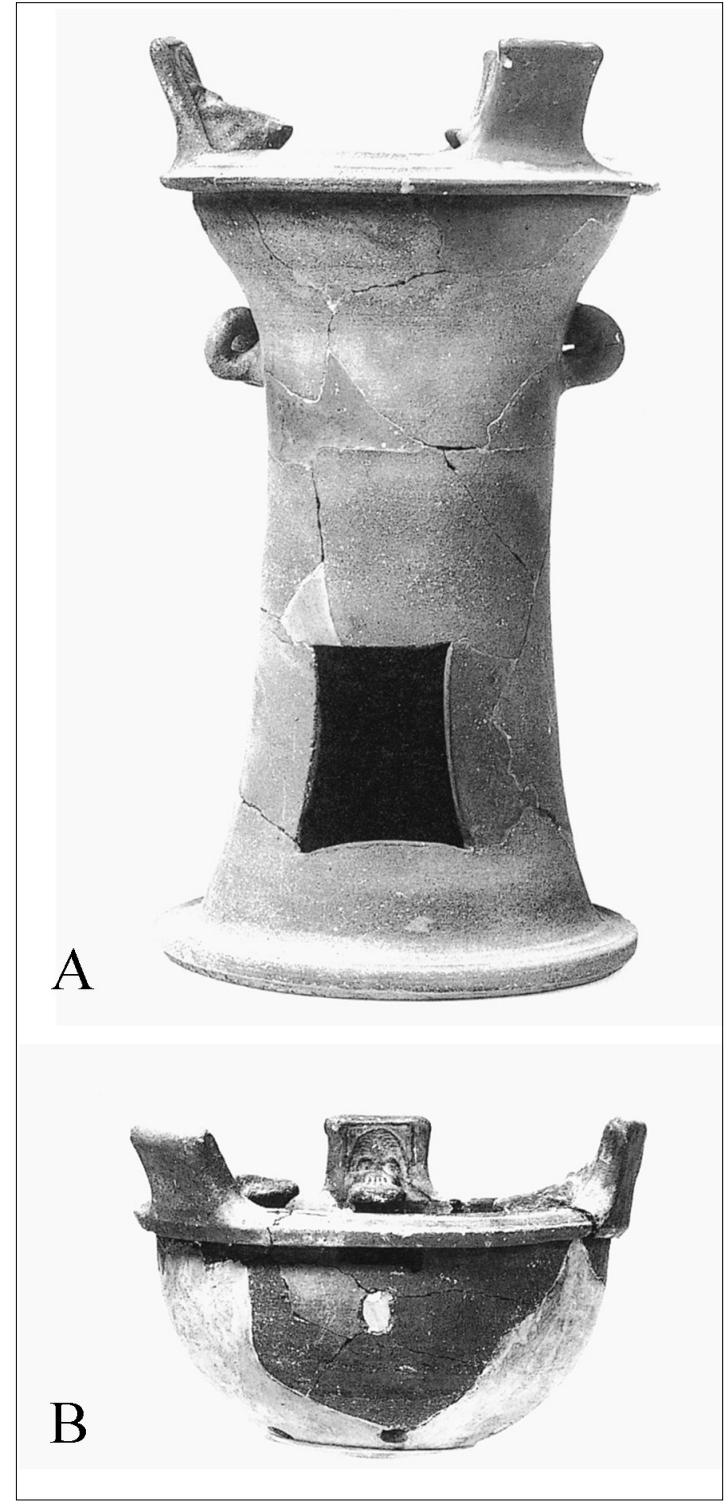

Figura 11. Klíbanos. Ágora de Atenas. A y B (Rotroff 2006, no 787, p. 200-204).

dices con cabezas humanas provistas de gorro cónico y larga barba, son siempre de la primera mitad del siglo II.

El tipo pasa pronto al Mediterráneo Central, conociéndose en la misma época en Sicilia aunque de manera más puntual, en algún caso asociado a ajuares de necrópolis como en Lilibeo (Di Stefano 1984: 75-76; Bechtold 1999: 150-151), lo que nos apunta una nueva funcionalidad. En la Carthago púnica se documenta en niveles relacionados con la destrucción de la ciudad, en contextos domésticos pero con po-

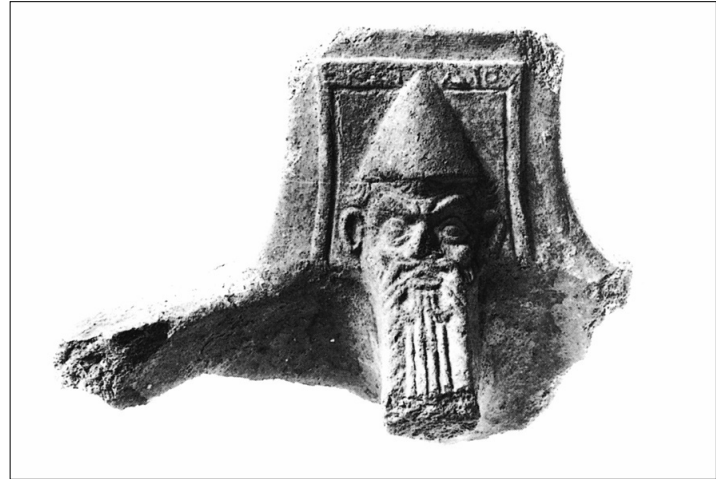

Figura 12. Soporte interior de klíbanos, con figuración de personaje barbado con gorro cónico. Ágora de Atenas (Rotroff, 2006, Type I.1, n 746, pl. 74, p. 205).

sible funcionalidad ritual (Lancel 1979: 213), quizás en un almacén con otros productos orientales, o bien sin contexto (Ferron y Pinard 1955: 60-73). Más sencillos, y como precedentes del 'canoun' bereber, los documenta Cintas en Susa, con cronología de 'siglos III-I a.C.' (Cintas 1950: 187, Lám. XLIX, no 76 y 77). El uso del 'canoun' con tres soportes es común hoy día en el Magreb, como hemos podido documentar recientemente en Marrakech (Fig. 13).

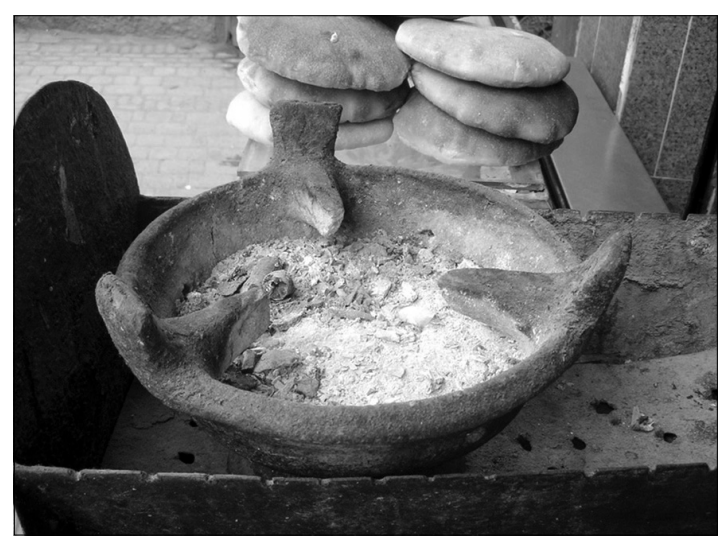

Figura 13. "Canoun" con tres soportes. Medina de Marrakech (foto autor).

\subsubsection{Aquí: contextos y posible funcionalidad en cultos públicos}

En Hispania Citerior han aparecido varios de estos soportes, en casi todos los casos con representación de cabeza masculina barbada tocado con gorro cónico. Los encontramos fechados en la primera mitad del siglo II en Emporiae, Burriac (Cabrera de Mar), Tarraco y Carthago Nova. La ubicación o los 
contextos de los clíbanos son las áreas forales de Tarraco y Emporiae (Dupré 1985: 138-139); el pozo votivo de L'Hostal (Burriac), con abundantes vasos para beber, ánforas y un candelabro (Cela et alii 2002); y en Carthago Nova en un relleno de la Plaza del Hospital fechable en la primera mitad del siglo II donde también se documentaron (aunque no en asociación clara) un cernos con cabeza femenina polícroma, una placa de cerámica con media cabeza de vaca en relieve igualmente policromada, y una cabecita de bulto redondo representando a un Dionisos niño (Pérez Ballester 1998: 257); las tres piezas de Cartagena, apéndices con figura barbada tocada con gorro cónico, son del tipo I.2a de Rotroff (2006: 205-206), fechado en la primera mitad del siglo II a.C. (Fig. 14). Curiosamente se hallaron al pie de la colina dedicada a Hefaistos, según Polibio $(\mathrm{X}, 10)$.

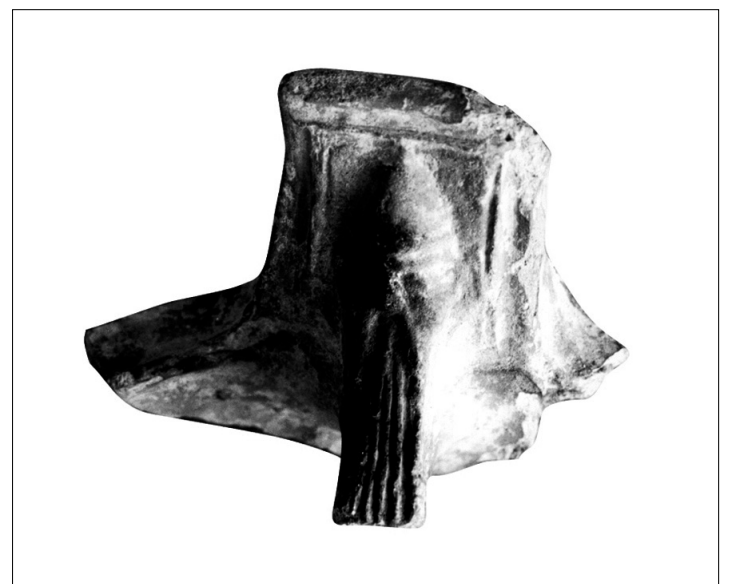

Figura 14. Soporte interior de klíbanos, con figuración de personaje barbado con gorro cónico. Hospital de Marina, Cartagena.

Estos tres contextos nos hacen pensar en una funcionalidad distinta a la doméstica: la parte superior del clíbanos, del que nos llegan siempre los apéndices decorados, se podría usar para contener un recipiente en el que quemarían incienso, esencias, ofrendas diversas, etc. Una funcionalidad similar se ha apuntado también para los que aparecieron en el santuario de Apolo Karneios en Knidos (Sahin, en Rotroff 2006: 201), interpretándolos como altares portátiles. El clíbanos sería pues, en contextos hispanos republicanos, más un quemaperfumes o altar que un hornillo, que se utilizaría en ambientes sacros o rituales más que domésticos; aunque su escasa presencia no permite asegurar esta propuesta.
2. ICONOGRAFÍA VASCULAR TARDO-HELENÍSTICA ORIENTAL EN EL MARCO DEL COMERCIO MARÍTIMO ROMANO REPUBLICANO (SEGUNDA MITAD SIGLO II PRIMERA MITAD I A.C.)

\subsection{LOS CUENCOS DE RELIEVES Y LOS LAGINOS DE ENGOBE BLANCO}

Hacia el último tercio del siglo II y durante la primera mitad del I a.C. encontramos especialmente en Cartagena y en su área de influencia directa, la pervivencia de una iconografía helenística de origen oriental, representada por los cuencos de relieves a molde de origen jonio y, en menor proporción pero creemos que directamente relacionados con ellos, las botellas o laginos de engobe blanco de procedencia minorasiática (Pérez Ballester 1994a, con bibliografía) (Fig. 15).

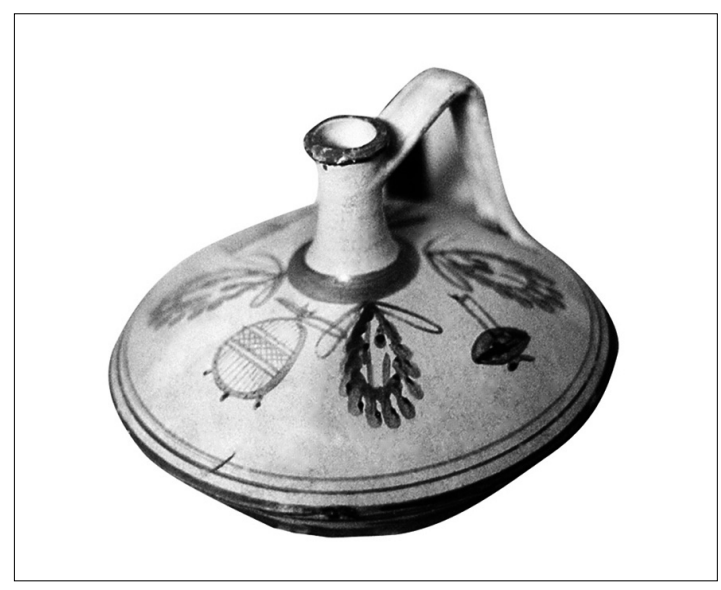

Figura 15. Laginos de engobe blanco. Museo de Corinto (Foto autor).

\subsubsection{Funcionalidad, iconografía y distribución}

El cuenco de relieves, con origen en copas metálicas para vino del Medio Oriente Persa o más adelante de Alejandría, tiene siempre esa concepción particular como cáliz vegetal, cáliz compuesto ahora por motivos a la vez variados y repetitivos, debido obviamente al uso de punzones móviles empleados en la elaboración de las matrices (Fig. 16). Como dice P. Cabrera, estamos ante unas composiciones decorativas en las que es patente la pérdida del contenido narrativo que encontrábamos en las cerámicas griegas del siglo Iv; ahora hay un acento en lo decorativo, en el ornamento en fin, como motivo prin- 
cipal de la decoración (Cabrera 2004: 12-13). Si en el siglo III e inicios del iI a.C., a través de las fíalas y las copas con medallones en relieve veíamos un repertorio de divinidades, héroes y animales enmarcados o no en roleos y teorías vegetales, que podían remitir directamente e entornos dionisíaco-órficos ctónicos o de banquete, ahora la decoración a molde parece alejada de los significantes primeros, que son solo evocados y que nos traslada la imagen de un modesto vaso para beber vino, que evidentemente es más apreciado en el extremo del Mediterráneo Occidental que en los lugares de donde proceden y existen talleres con una gran producción, una cierta capacidad de desplazamiento e intercambio de punzones, como bien ha estudiado Siebert (1978 y 1987). En Asia Menor, algunos contextos comienzan a revelar su posible uso ritual en santuarios como los de Hierópolis de Frigia y Iasos de Caria, aunque con una iconografía muy concreta (Semeraro 2005: 96).

La llegada por mar a nuestras tierras de estas copas acompañadas de laginos (botellas para servir vino) de engobe blanco, en barcos que llegan desde Campania con cargamentos de vino itálico como creo que hemos demostrado (Pérez Ballester 1994a), hace que propongamos que su funcionalidad al menos en Carthago Nova, sería similar a la que tuvo en las ciudades helenísticas del Mediterráneo Oriental: un servicio de copas y jarra para el consumo de vino, quizás un vino especial, el vino griego. La falta de asociaciones claras nos impide proponer un uso ritual que no sería extraño, dada la singularidad de este servicio jarra/copa.

Su concentración en Carthago Nova (más de 200 cuencos de relieves y unos 50 laginos) y área de influencia es evidente: 26 cuencos y 2 laginos en Ilici; 8 cuencos en El Monastil, Elda; otros en Archena y Cabecico del Tesoro (Murcia); Tossal de Manises, La Albufereta y Santa Pola (Alicante), (Tordera 1991 y Cabrera 2005). Pudo deberse a la temprana presencia de una colonia oriental en Carthago Nova basándose en otros indicios, como también se ha señalado (Pérez Ballester 1998: 254-257; Uroz Rodríguez 2005). En cuanto a Ilici, Cabrera apunta la posibilidad de que las abundantes rosetas que aparecen en estos vasos tuvieran un atractivo especial para el ilicitano, por la identificación con el símbolo de su diosa principal, como han propuesto R. Olmos y T. Tortosa. Su presencia más al norte, también con algún fragmento de laginos, marca las principales áreas portuarias valencianas como Valentia y $\mathrm{Sa}$ guntum, y penetran hacia el interior: La Moleta dels Frares (El Forcall), La Romana (Zaragoza), siendo

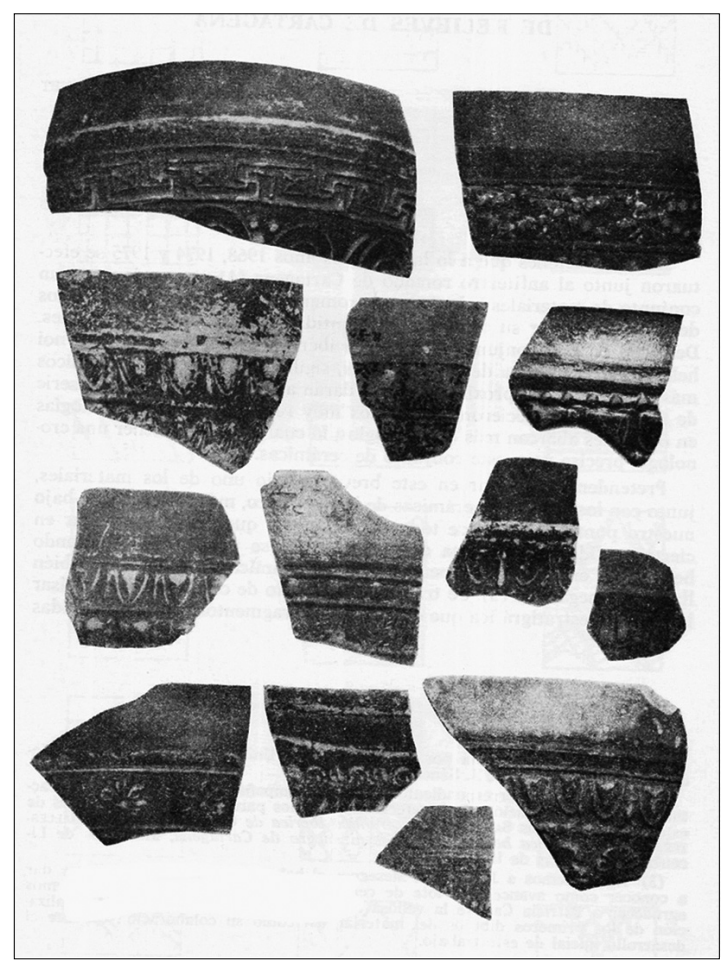

Figura 16. Fragmentos de cuencos de relieves orientales. Área del Anfiteatro, Cartagena. (Cabrera 1980).

raros en Cataluña, salvo en Tarraco, Burriac y Emporiae. En Mallorca, aparecen puntualmente en contextos de fines del siglo II a.C., como en el interesante conjunto del Turó de les Abeilles. ${ }^{13}$ En Andalucía hallamos cuencos aislados desde Villaricos (Almería) a Sevilla (Jaeggï 1999: Karten 3) (Fig. 17).

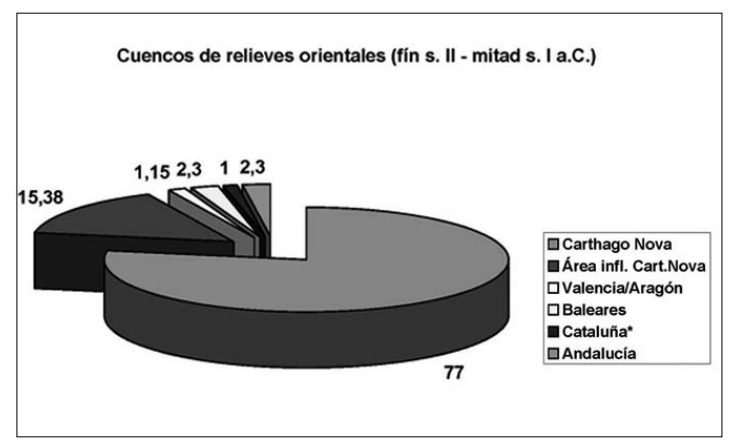

Figura 17. Distribución de los cuencos de relieves orientales en la Península Ibérica (elaboración propia).

${ }^{13}$ Cuenco de relieves, laginos y una copa de barniz rojo con relieve de Isis y Serapis (Camps y Vallespir 1998: fig. 15,16 y 73 ; Blech, Camps y Vallespir 1978). 
Los laginos, con su naturalista decoración pintada (guirnaldas, coronas con lemniscos, instrumentos musicales, laginos) sobre un brillante fondo blanco, alusiva a los banquetes en donde se utilizaban (Fig. 18) supondrían un extra de prestigio a la hora de servir el vino para el propietario el mismo. Hay que decir sin embargo, que en otros contextos no menos helenizados del Mediterráneo Central, pero quizás con otras prioridades, cuencos de relieves y laginos aparecen en ambientes funerarios, en donde la iconografía de banquete, en cuanto que dionisíaca, sería fácilmente aceptada para realizar libaciones u ofrendas a sus difuntos, como en Lilibeo, Sicilia (Di Stefano 1984: 116-117; Bechtold 1999: 133 y 366) o en Cagliari (Cerdeña). ${ }^{14}$

\section{AQUÍ Y ALLÍ: MISMAS ÉPOCAS, DISTINTOS CONTEXTOS, DIFERENTES FUNCIONALI- DADES. RECAPITULACIÓN}

Hemos presentado un conjunto de vasos helenísticos, portadores de iconografía. Se trata de producciones variadas, fechadas entre la mitad del siglo III y la mitad del i a.C., que llegan en pequeñas cantidades a nuestras costas. No debemos olvidar que estamos ante unas imágenes que han perdido el carácter narrativo de la época clásica; ahora predomina el carácter ornamental y representativo de las composiciones, el gusto por lo pequeño, lo raro, lo oculto. Y en donde lo simbólico y lo críptico iba unido al desarrollo de cultos como los dionisíacos y los órficos.

En general, vemos un uso distinto de esos vasos en Iberia/Hispania con respecto a sus lugares de origen. En efecto, en la segunda mitad del siglo III, las cerámicas sobrepintadas 'De Gnathia', de presencia muy puntual, se encuentran en ambientes de oppida indígenas o de ciudades como Cartagena, siempre muy próximas al mar. Presentan una iconografía familiar al ibero, aunque no la interpreta como el itálico: este le concede un uso exclusivamente funerario, mientras que en Iberia, sin descartar la valoración iconográfica, pensamos que se debió usar como copa de prestigio para beber; beber un vino exótico y preciado, seguramente el que llegaba en las ánforas grecoitálicas de Sicilia o Magna Grecia.

A finales de ese siglo e inicios del II, fíalas y copas decoradas con relieves, la mayoría barnizadas de negro, llegan a Hispania Citerior y se difunden por

${ }^{14}$ Necrópolis de Tuvixeddu (Cagliari), Tumba 110, Museo Arqueológico de Gagliari. Fines del siglo II - inicios I a.C.

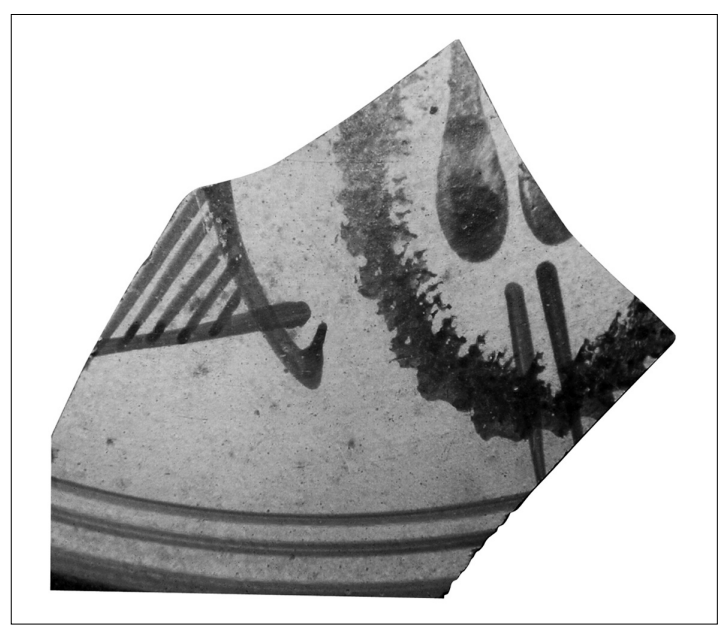

Figura 18. Fragmento de laginos de engobe blanco. Área del Anfiteatro de Cartagena.

ciudades y oppida ibéricos costeros, llegando también a algunos lugares del interior. Las fíalas que en Italia aparecen en contextos funerarios y sacros conservan en Hispania esta última funcionalidad, halladas casi siempre en entornos sacros públicos, salvo el ejemplar de Alcoi, en un posible ambiente de culto doméstico indígena, mientras que los hallados en las minas de Cartagena y Jaén podrían estar relacionados con cultos ctónicos. Las copas y las pateritas parecen más vinculadas a ambientes privados, o al menos no claramente públicos.

Algo más tarde, los singulares clíbanos de origen oriental hallados en la península han perdido aquí su primitiva función de hornillo o calentador, y por sus contextos proponemos que estaban vinculados a fines rituales, en donde su función sería la de quemaperfumes o quizás la de altar portátil. La imagen que figura en los apéndices o apliques: cabeza barbada tocada con pilos, parece que aludiría al propio $\mathrm{He}$ faistos o a un demon relacionado con el fuego, y tal cual podría ser aceptado por el hispano helenizado que lo usa; especialmente en Carthago Nova, donde como hemos comentado se encontraron en las inmediaciones del cerro dedicado a Efaistos.

A fines del siglo II e inicios del I a.C., cuencos de relieves y laginos de engobe blanco minorasiáticos, con decoración alusiva directa o indirecta al mundo dionisíaco y del banquete, creemos que mantienen su función originaria de servir y consumir vino, seguramente vino griego; no descartamos su posible utilización en libaciones rituales en contextos sacros.

La iconografía que contiene este conjunto de vasos es aceptada por el indígena de diferentes maneras: la de las copas 'De Gnathia' la vemos en otros 
objetos ibéricos, de cerámica o no, pero siempre de prestigio o asociados a ajuares ricos; la asociación de estos vasos con ritos o cultos ibéricos solo está documentada en el hallazgo de una pieza en el santuario de La Encarnación de Caravaca (Murcia), que podría ser un exvoto dejado por un importante personaje, según sus excavadores. La iconografía de las fíalas de relieves nos llega a la península muy seleccionada: de una parte los temas más frecuentes en Italia, como las Ornamentschale; pero son también frecuentes otros como la Apoteosis de Heracles. La vinculación de este héroe con la fundación legendaria de ciudades en Hispania, y su repetida aparición en monedas contemporáneas, podría estar en la relativa popularidad de este tema, sin olvidar la relación del héroe y del tema apoteósico con las creencias en una vida después de la muerte, fundamental en cultos dionisíacos y órficos. Otros alusivos al mundo dionisíaco (erotes, guirnaldas) son muy frecuentes en todo tipo de ornamentaciones helenísticas, y pudieron usarse en cultos públicos, como se ha dicho. En las fíalas, creemos que la forma condicionaría la función, por encima de las representaciones iconográficas que portan. La variedad de imágenes que aparecen también en los fondos de cuencos profundos y las pequeñas pateritas y su aceptación por el individuo local, que merecen un estudio más detallado que no tiene espacio aquí, debieron tener diferente lectura según se tratase de gentes itálicas o muy helenizadas de Carthago Nova o Tarraco, por ejemplo, o de gentes ibéricas, en donde seguramente la posesión del objeto en cuanto que raro concedía y otorgaba un prestigio a quien lo poseía, sin descartar la posibilidad la apreciación del componente mágico o religioso que desprenderían sus imágenes.

La iconografía de los cuencos de relieves tardíos está alejada desde el mismo momento de su fabricación en Oriente de programas mitológicos o sacros concretos, salvo excepciones que no se documentan en Hispania (p.e. los vasos 'homéricos', o los figurados de Hierópolis de Frigia), debido a la multiplicidad de talleres y la composición de frisos decorativos con la combinación de numerosos punzones y a su fabricación seriada. No descartamos sin embargo la posibilidad apuntada por Cabrera para Ilici, donde la compleja roseta de la base del cuenco o las numerosas rosetas que aparecen en los vasos, remitiera al ilicitano al símbolo de su divinidad principal, como ya hemos comentado.

En cuanto a los laginos, sus programas decorativos realistas aluden directamente al consumo de vino de tipo convivial. Aquí las imágenes pintadas del vaso, contenido (vino) y consumo son los mismos en Oriente y en ciudades helenizadas costeras de Hispania, especialmente en Carthago Nova, donde el asentamiento de una comunidad miniorasiática pudo facilitar la llegada de partidas de vino griego, laginos para servirlo y copas para beberlo, siguiendo un trayecto marítimo que arrancaría de Delos, recalaría en Puteoli donde se embarcarían en naves cargadas de vino campano, ${ }^{15}$ y llegarían a puertos como el de Carthago Nova, desde donde se redistribuirían.

\section{BIBLIOGRAFÍA}

Abad, L. 1983: "Un conjunto de materiales de La Serreta de Alcoy", Lucentum 5, 173-197.

Aranegui, C. 1995: "Un ánfora de TR.LOISIO en Sagunto (Valencia)", Extremadura Arqueológica 5, 247-263.

Bechtold, B. 1999: La necropoli di Lylibeum, Roma.

Blech, M., Camps, J. y Vallespir, A. 1978: "Eine reliefschale aus Mallorca", Madrider Mitteilungen, 19, 231-237.

Cabrera Bonet, P. 1980: "La cerámica helenística de relieves de Cartagena", Cuadernos de Prehistoria y Arqueología de la Universidad Autónoma de Madrid 5-6, 81-104.

Cabrera Bonet, P. 1998: "Dioniso en un jardín. El espacio de la iniciación en la iconografía de los vasos apulios", C. Sánchez y P. Cabrera (eds.), En los límites de Dioniso, Murcia, 61-88.

Cabrera Bonet, P. 2004: "Vasos cerámicos de importación de lujo del Mediterráneo oriental y central", R. Olmos y P. Rouillard (coords.), La vajilla ibérica en época helenística, 5-18, Collection de la Casa de Velázquez 89, Madrid.

Cabrera Bonet, P. 2005: "La cerámica helenística de relieves de La Alcudia (Elche)", T. Tortosa (coord.), El yacimiento de La Alcudia: pasado y presente de un enclave ibérico, Anejos de Archivo Español de Arqueología 55-70, Madrid.

Camps, J. y Vallespir, A. 1998: Excavacions a Santa Ponça, Mallorca. El Turó de les Abelles, Col.lecció La Deixa 1, Palma de Mallorca.

Cela, X., Zamora, D. y Revilla, V. 2002: "El jaciment de l'Hostal (Cabrera de Mar, Maresme)", Laietania $13,49-68$.

Cintas, P. 1950: Céramique Punique, Inst. Hautes Études, 3 Tunis.

${ }^{15}$ Laginos de engobe blanco, en pecios como el de La Cavalière, Spargi, Sant Jordi y más recientemente en Escombreras 2 (Cartagena), con cargamentos mayoritarios de ánforas vinarias Dr.1. 
De Juliis, E. M. 1985: Gli Ori di Taranto in Età Ellenistica, Catalogo della Mostra, Milano.

De Lucia Brolli, M. A. y Michetti, L. M. 2005: "La ceramica a rilievo di produzione falisca", Melànges École Française de Rome, 117, 1, 137-171.

Di Stefano, C. A. 1984: Lilibeo. Testimonianze archeologiche dal IV sec. a.C. al v sec. d.C., Palermo.

Domergue, J. Cl. 1969: "Céramique de Cales dans les antiques mines d'argent de Carthagène", Archivo Español de Arqueología 42, 159-165.

Dupré i Raventós, X. 1985: "Nanses de fogó amb decoració de cap de Silé”, Fonaments 5, 137-146.

Ferron, J. y Pinard, M. 1955: "Les fouilles de Byrsa: 1953-1954”, Cahiers de Byrsa V, 31-264.

Gambogi, P. y Paladino, S. 1999: Castiglioncello. La necropoli ritrovata, Catalogo della Mostra, Rossignano Maritimo.

Gianfrotta, P. A., Nieto, X., Pomey, P. y Tchernia, A. 1997: La Navigation dans l'Antiquité, Aix-enProvence.

Green, J. R. 1982: "The Gnathian pottery of Apulia”, M. E. Mayo (ed.), Vases from Magna Graecia, Richmond, 252-259.

Green, J. R. 2001: “Gnathia and other Overpainted Wares of Italy and Sicily: A survey", P. Levèque y J.P. Morel (ed.), Cèramiques Hellénistiques et Romaines 3, 57-103.

Jaeggï, O. 1999: Der Hellenismus auf der Iberischen Halbinsel : Studien zur iberischen Kunst und Kultur: das Beispiel eines Rezeptionsvorgangs, Mainz am Rhein.

Lancel, S. et alii, 1979: Byrsa I. Rapport préliminaires des fouilles (1974-1976), Collection École Française de Rome 40, Paris.

Lancel, S. et alii, 1982: Byrsa II. Mission Archéologique Française à Carthage (1977-1978), Collection École Française de Rome 41, Paris.

Lippolis, E. 1994: "Phialai Mesophaloi: ceramiche con decorazione a rilievo del Museo Nazionale di Taranto", Studi di Antichità 7, 235-250.

Lippolis, E. 1996: Taranto la necropoli: aspetti e problemi della documentazione archeologica dal VII al I sec. A.C., Catalogo del Museo Nazionale Archeologico di Taranto, III, 1, Taranto.

Marín, C.y Ribera, A., 2001: "Las cerámicas de barniz negro de Cales en Hispania”, L. Pedroni (ed.), Ceramica Calena a vernice nera, 246-295, Città di Castello.

Martín Camino, M. 1996: "Relaciones entre la Cartagena pre-bárquida y la Magna Grecia y Sicilia antes de la Primera Guerra Púnica. Consideracones a partir de algunas marcas de ánforas (I)", Cuadernos de Arqueología Marítima 4, 11-37.
Massa-Peirault, F. H. 2005: "L'image antique et son interprétation", Melànges École Française de Rome 117, 1, 11-15.

McCann, M. 1972: "Maria SS. Di Altomare". A Fourth Century B.C. Shipwreck Near Taranto, Archaeology 25, 180-187.

Morel, J. P. 1978: “À propos des céramiques campaniennes de France et d'Espagne", Archéologie en Languedoc 1, 149-168.

Morel, J. P. 1980 : "La céramique campanienne. Acquis et Problèmes",Céramiques Hellenistiques et Romaines I, Centre de Recherches d'Histoire Ancienne 36, Besançon, 85-122.

Morel, J. P. 1981: Céramique Campanienne. Les Formes, Bibliothèque École Française de Rome 244, Roma.

Pagenstecher, R. 1909: Die Calenische Reliefkeramik, Jahrbuch der Deutsches Archäologisches Institut VIII, Berlin.

Pedroni, L. 2001: Cerámica calena a vernice nera. Produzione e diffusione, Città di Castello.

Pérez Ballester, J. 1994a: "Asociaciones de lagynoi, boles de relieves y ánforas rodias en contextos mediterráneos", Huelva Arqueológica 12, 2, 347 366.

Pérez Ballester, J. 1994b: "La cuestión de las importaciones itálicas al sur del Ebro anteriores a las Guerras Púnicas. A propósito de un vaso de Gnathia procedente de Ibiza”, Saguntum 27, 189-205.

Pérez Ballester, J. 1997: “Decoraciones geométricas, vegetal y figurada: tres grupos de motivos interrelacionados", C. Aranegui (ed.), Damas y Caballeros en la Ciudad Ibérica, 117-160, Madrid.

Pérez Ballester, J. 1998: "El Portus de Carthago Nova. Sociedad y comercio Tardohelenísticos", J. Pérez Ballester y G. Pascual Berlanga (eds.), Puertos Antiguos y Comercio Marítimo. Actas III Jornadas Intern. de Arqueología Subacuática, Valencia, 250-261.

Pérez Ballester, J. 2002: Vasos sobrepintados italiotas del Museo Arqueológico Nacional de Madrid, Murcia.

Pérez Ballester, J. 2004: "La producción y el comercio del vino itálico en el Mediterráneo Occidental", M. Lechuga (coord.), Scombraria. La Historia oculta bajo el mar. Catálogo de la exposición, Murcia, 22-29.

Pérez Ballester y J. Gómez Bellard, C. 2004: "Imitaciones de vasos plásticos en el mundo Ibérico", R. Olmos y P. Rouillard (coords.), La vajilla ibérica en época helenística, Collection de la Casa de Velázquez 89, Madrid. 31-48.

Principal, J. 1998: Las importaciones de vajilla fina 
de barniz negro en la Cataluña sur y occidental durante el s. III a.C. Comercio y dinámica de adquisición en las sociedades indígenas, BAR International Series 729, Oxford.

Puche, J. M. 1998: "Les ceràmiques calenes a Tarraco. Les decoracions a relleu i avanç de les produccions del segle II a.C.", Revista d'Arqueologia de Ponent 8, 107-127.

Richter, G. M. A. 1950: "Greek fifth-century silverware ad later imitations", American Journal of Archaeology 54, 357-370.

Richter, G. M. A. 1959: "Calenian pottery and Classical Greek Metalware", American Journal of Archaeology 63, 241-249.

Rocco, A. 1959: "Caleni Vasi", Enciclopedia de l'Arte Antica 2, 271-272.

Rotroff, S. I. 2006: Hellenistic Pottery. The Plain Wares. The Athenian Agora XXXIII, Athens.

Ruiz Valderas, E. 1994: "Las cerámicas de barniz negro de Cales en la primera mitad del siglo II a.C. en el Cerro del Molinete (Cartagena)", Revista d'Arqueologia de Ponent 4, 47-66.

Ruiz Valderas, E. 1999: "Las cerámicas campanienses del siglo III a.C. en Cartagena: el Cerro del Molinete", XXIV Congreso Nacional de Arqueología (Cartagena 1997), Murcia, 33-42.

Ruiz Valderas, E. 2004: “Cerámicas campanienses de Cartagena: el registro arqueológico y el registro comercial", M. Lechuga (coord.), Scombraria. La Historia oculta bajo el mar. Catálogo de la exposición, Murcia, 89-106.

Ruiz Valderas, E. 2008: "La cerámica de barniz negro en el registro estratigráfico de Carthago Nova.
De la fundación bárquida a la conquista romana", J. Uroz, J. M. Noguera y F. Coarelli, (eds.), Iberia e Italia: Modelos romanos de integración territorial, Murcia, 669-686.

Sanesi, L. 1982: "La patera ombelicata con quadrighe del Museo Archeologico di Adria: rapporti con la produzione etrusco-volterrana", Padusa 3, 7483.

Semeraro, G. 2005: "Per un approccio contextuale alla lettura delle imagini. Le ceramiche a rilievo de Hieropolis di Frigia", Melànges École Française de Rome 117, 1, 83-98.

Siebert, G. 1970: "Réchauds", Ph. Bruneau (dir.), Delos XXVII. L'îlot de la maison des Cómediens, 267-276.

Siebert, G. 1978: Recherches sur les ateliers de bols à reliefs du Péloponnèse à l'époque hellénistique, Bibliothèque École Française d'Athènes et Rome 233, Athènes.

Siebert, G. 1987: "Les bols à reliefs. Une industrie d'art de l'époque hellénistique", Céramiques Hellénistiques et Romaines, Centre de Recherches d'Histoire Ancienne 36, Besançon.

Tordera Guarinos, F. F. 1991: "Boles helenísticos en relieve en el poblado de El Monastil", Alebus 1, 9-32.

Uroz Rodríguez, H. 2005: "Sobre la temprana aparición de los cultos de Isis, Serapis y Caelestis en Hispania”, Lucentum 23-24, 165-180.

Wyler, St. 2004: "Dyonisos Domesticus. Les motifs dionysiaques dans les maisons pompéiennes et romaines (II s. av. - I s. ap. J.C.)", Melànges École Française de Rome 116, 933-951. 